Volume 54

Issue 1 New York Law School Law Journal

Alumni Issue

Article 6

January 2009

\title{
Conflict of Law and Surreptitious Taping of Telephone Conversations
}

Carol M. Bast

University of Central Florida, Orlando

Follow this and additional works at: https://digitalcommons.nyls.edu/nyls_law_review

Part of the Communications Law Commons, Conflict of Laws Commons, Constitutional Law Commons, and the Privacy Law Commons

\section{Recommended Citation}

Carol M. Bast, Conflict of Law and Surreptitious Taping of Telephone Conversations, 54 N.Y.L. ScH. L. REV. 147 (2009-2010).

This Article is brought to you for free and open access by DigitalCommons@NYLS. It has been accepted for inclusion in NYLS Law Review by an authorized editor of DigitalCommons@NYLS. 


\section{Conflict of Law and Surreptitious Taping of Telephone Conversations}




\section{INTRODUCTION}

Hardly a day passes without communicating with someone via the telephone. The prevalence of cellular telephones has only increased our ability to reach out and touch someone from virtually any location. Often, one party to the telephone conversation audiotapes the conversation to have a record of what the parties discussed-out of simple curiosity; to take notes of the substance of the conversation; to gather information that could put the person taping at a social, political, or economic advantage; or to gather evidence in anticipation of litigation.

Although the federal government and a majority of states allow surreptitious taping of a telephone conversation with one-party consent, this practice violates state statutes in ten states. ${ }^{1}$ Thus, courts are faced with the question: What law applies when surreptitious taping of a telephone conversation involves more than one jurisdiction, and one jurisdiction requires all parties to consent and the other does not? This paper explores how courts have dealt with this question. ${ }^{2}$

In Part II, this paper provides the reader with background on wiretapping statutes. In Part III, the various conflict of law approaches among the states are outlined. In Part IV, this paper delves into the question of whether the courts have followed the conflict of law approaches of the various states. In Parts V and VI, this paper examines cases dealing with this question; first from a conflict of law perspective, then from the perspective of whether the court has jurisdiction over the defendant, and finally from the perspective of whether an exclusionary rule applies. In Part VII, a discussion of the variables in surreptitious interstate taping of telephone conversations is presented. In Part VIII, the final section attempts to provide some analysis that might be helpful in future cases.

The lesson to be learned is that one should be wary of surreptitiously taping a telephone conversation because this practice can easily subject the person taping to civil penalties and criminal charges. The person surreptitiously taping a telephone conversation may not know whether it is legal to do so in the state where the taping is made or whether it is legal to do so in the state where the non-consenting party is located. As a result of increasing cellular telephone usage, the person may not even know the state in which the other party to the conversation is located. ${ }^{3}$ The situation is further complicated if the telephone conversation is a conference call with multiple parties to the conversation potentially located in two or more states.

1. See infra notes $15-16$ and accompanying text.

2. This paper does not discuss cases in which the conversation and the secret taping occurred in one jurisdiction and the government seeks to use the taped information in another jurisdiction, nor does it discuss cases involving the Federal Wiretapping Act.

3. With cellular telephones, the area code is no longer a reliable indicator of the geographical location of the caller. A person desiring to surreptitiously tape a conversation could inquire where the other party is located, but the response might not be accurate. 


\section{FEDERAL AND STATE WIRETAPPING STATUTES}

To discuss the choice of law question concerning a surreptitiously taped telephone conversation, one must first understand the basics of federal and state wiretapping statutes. This section summarizes the most important principles of the federal wiretapping statutes, and then provides an overview of state wiretapping statutes.

Federal wiretapping statutes [hereinafter the "Federal Act"] ${ }^{4}$ make it a crime to secretly audiotape ("intercept") 5 a telephone conversation ("a wire communication"), ${ }^{6}$ to use the information on an illegally made tape, or to disclose the information that was illegally taped. ${ }^{7}$ There are, however, certain exceptions to this protection afforded telephone conversations under the Federal Act. The Federal Act allows someone who is a party to the telephone conversation to surreptitiously tape the conversation so long as the purpose of the taping is other than to commit a crime or tort. ${ }^{8}$ In

4. $\quad 18$ U.S.C. $\S \S 2510-2522$ (2006).

5. See $\$ 2510(4)$.

6. The Federal Act protects oral communication, wire communication, and electronic communication against being intercepted illegally. An oral communication is a face-to-face conversation made with a reasonable expectation of privacy. See $\S 2510(2)$. A violation of the Federal Act with respect to an oral communication is generally referenced as eavesdropping. A telephone conversation is usually classified as a wire communication because it is audible by the human ear. See $\S 2510(1)$. Section 2510(1) provides:

"[W]ire communication" means any aural transfer made in whole or in part through the use of facilities for the transmission of communications by the aid of wire, cable, or other like connection between the point of origin and the point of reception (including the use of such connection in a switching station) furnished or operated by any person engaged in providing or operating such facilities for the transmission of interstate or foreign communications or communications affecting interstate or foreign commerce.

Id. An electronic communication is digital information. § 2510(12). Although a telephone conversation may very well be transmitted digitally at some point, it is not usually thought of as an electronic communication because it is audible by the human ear at at least one point during transmission.

$[T]$ he term "wire communication" means the transfer of a communication which includes the human voice at some point. ... Thus, a wire communication encompasses the whole of a voice telephone transmission even if part of the transmission is carried by fiber optic cable or by radio-as in the case of cellular telephones. . . The conversion of a voice signal to digital form for purposes of transmission does not render the communication non-wire. The term "wire communication" includes existing telephone service, and digitized communications to the extent that they contain the human voice at the point of origin, reception, or some point in between.

H.R. Rep. No. 99-647 (1986); S. Rep. No. 99-541, at 12 (1986), as reprinted in 1986 U.S.C.C.A.N. $3555,3566$.

7. See 18 U.S.C. $§ 2511(1)$.

8. $§ 2511(2)(d)$. Sub-section (d) provides:

It shall not be unlawful under this chapter for a person not acting under color of law to intercept a wire, oral, or electronic communication where such person is a party to the communication or where one of the parties to the communication has given prior consent to such interception unless such communication is intercepted for the purpose of committing any criminal or tortious act in violation of the Constitution or laws of the United States or of any State. 
addition, a police officer may secretly tape a telephone conversation if the police officer is a party to the conversation, or a party to the conversation consents to the police officer surreptitiously taping the conversation. ${ }^{9}$ Meanwhile, the government can obtain a court order to surreptitiously tape a telephone conversation without the consent of any party to the conversation. ${ }^{10}$ The penalty for violating the Federal Act is up to five years imprisonment or a fine, ${ }^{11}$ and an illegally taped telephone call is inadmissible as evidence in a trial. ${ }^{12}$ The Federal Act also provides for civil lawsuits. A person whose telephone conversation has been surreptitiously taped in violation of the Federal Act has a private right of action for compensatory damages, punitive damages, attorney's fees and costs, and can obtain injunctive relief. ${ }^{13}$

All of the fifty states, except for Vermont, have statutes protecting the privacy of telephone conversations. Many state wiretapping statutes contain provisions similar to those contained in the Federal Act and generally permit taping upon the consent of one party to the telephone conversation. Other statutory provisions in those states largely mirror the federal provisions. ${ }^{14}$

One fifth of the states permit a party to surreptitiously tape a telephone conversation only upon consent of all parties to the conversation. These all-party consent states are California, Connecticut, Florida, Illinois, Maryland, Massachusetts, Montana, New Hampshire, Pennsylvania, and Washington. ${ }^{15}$ All-party consent is

9. $\$ 2511(2)(c)$ ("It shall not be unlawful under this chapter for a person acting under color of law to intercept a wire, oral, or electronic communication, where such person is a party to the communication or one of the parties to the communication has given prior consent to such interception.").

10. See 18 U.S.C. $\S \S 2516-2519$.

11. $§ 2511(4)(a)$. Section 2511(5)(a) allows the government to obtain an injunction against further violation. See $\$ 2511(5)$ (a); See also 2521 (the government may obtain an injunction against someone violating the Federal Act).

12. § 2515 . Section 2515 provides:

Whenever any wire or oral communication has been intercepted, no part of the contents of such communication and no evidence derived therefrom may be received in evidence in any trial, hearing, or other proceeding in or before any court, grand jury, department, officer, agency, regulatory body, legislative committee, or other authority of the United States, a State, or a political subdivision thereof if the disclosure of that information would be in violation of this chapter.

Id.

13. $§ 2520$.

14. See supra notes 8-13 and accompanying text. See also Carol M. Bast, What's Bugging You? Inconsistencies and Irrationalities of the Law of Eavesdropping, 47 DePaul L.Rev. 837 (1998). Until 1999, Delaware was an all-party consent state. With the passage of new statutes in 1999, it became a one-party consent state. Del. Code Ann. Tit. 11, §§ 2401-2409 (2007).

15. From reading its statute, Michigan would seem to be an all-party consent state; however, case law has interpreted Michigan's wiretapping statute to allow surreptitious taping upon one-party consent. The theory behind this case law interpretation is that a party cannot "intercept" the party's own conversation. Bast, supra note 14 , at $878-81$. Although the Connecticut statutes allow one party to a face-to-face conversation to surreptitiously tape the conversation, the statutes require all-party consent to tape a telephone conversation. $I d$. at 927 . 
required when the parties to a telephone conversation are private individuals; however, in those states, the general rule is that a party to the telephone conversation can tape the conversation so long as the consenting party is a police officer or informant. Other statutory provisions in those states largely mirror the federal statutes. ${ }^{16}$

The following section provides basic information on the various conflict of law approaches.

\section{CONFLICT OF LAW APPROACHES VARY AMONG THE STATES}

One determinate in predicting the result a court will reach in a surreptitious taping case is the conflict of law approach followed by a particular state, with the states varying in their approaches. Classification of the conflict of law approach of a particular state can be problematic because the case law in the state may not be particularly clear, and the approach may differ depending on whether the subject matter of a case is tort or contract. Symeon C. Symeonides identified seven conflict of law approaches with regard to tort cases: the traditional approach (i.e., lex loci delicti), the significant contacts approach, the Second Restatement approach, the interest analysis approach, the lex fori approach, the better law approach, and the combined modern approach. ${ }^{17}$

As of January 2007, with regard to tort cases, ten states followed the traditional approach, two states and Puerto Rico followed the significant contacts approach, twenty-three states followed the Second Restatement, two states and the District of Columbia followed the interest analysis approach, two states followed the lex fori approach, five states followed the better law approach, and six states followed the combined modern approach. ${ }^{18}$

The traditional approach to torts was the foundation of the Restatement (First) of Conflict of Laws. ${ }^{19}$ The territoriality concept is powerfully reflected in the portion

16. See Bast, supra note 14. Some all-party consent states require authorization prior to a police officer or an informant surreptitiously taping a telephone conversation, or the states limit the taping to gathering evidence of certain types of crimes. For example, New Hampshire and Washington require authorization in advance of the taping. See infra notes 113-16, 149-54, 177 and accompanying text.

17. Symeon C. Symeonides, The American Choice-of-Law Revolution in the Courts: past, present and Future 64 (2006) [hereinafter Symeonides, Choice of Law Revolution].

18. Symeon C. Symeonides, Choice of Law in the American Courts in 2006: Twentieth Annual Survey, 54 Am. J. Comp. L. 697, 712-14 (2006). The ten states following the traditional approach are Alabama, Georgia, Kansas, Maryland, New Mexico, North Carolina, South Carolina, Virginia, West Virginia, and Wyoming. The two states following the significant contacts approach are Indiana and North Dakota. The twenty-three states following the Second Restatement are Alaska, Arizona, Colorado, Connecticut, Delaware, Florida, Idaho, Illinois, Iowa, Maine, Mississippi, Missouri, Montana, Nebraska, Nevada, Ohio, Oklahoma, South Dakota, Tennessee, Texas, Utah, Vermont, and Washington. The two states following the interest analysis approach are California and New Jersey. The two states following the lex fori approach are Kentucky and Michigan. The five states following the better law approach are Arkansas, Minnesota, New Hampshire, Rhode Island, and Wisconsin. The six states following the combined modern approach are Hawaii, Louisiana, Massachusetts, New York, Oregon, and Pennsylvania. Id.

19. See Restatement (First) of Conflict of Laws $§ 378$ (1934). 
of the First Restatement concerning torts, with the physical location of the tort determining which state's law is to be applied. ${ }^{20}$ The First Restatement was mechanical in operation, with the result of the lawsuit being tied to the location of the tort, rather than other, perhaps more appropriate, factors. The result, however, was predictable; it gave the law certainty, and made it less likely for the plaintiff to forum shop to obtain the best result. ${ }^{21}$

A court following the Restatement (Second) of Conflict of Laws approach in a torts case must consider sections 6 and 145 of the Second Restatement. Section 6 requires the court to consider factors not directly related to the alleged wrong and the parties. ${ }^{22}$ These factors include: the relationships among the states and among nations, the policies of the forum state and other states with ties to the alleged wrong or the parties, the governmental interests of the forum state and other states with ties to the alleged wrong or the parties, the expectations of those involved, the policies of the field of law underlying the lawsuit, the predictability of the result reached by the forum, and the ability of the forum to determine and apply the law to the lawsuit. ${ }^{23}$ In determining the relationship among the various states, the alleged wrong, and the parties, section 145 directs the court to consider: the location of the alleged wrong, the location of the action that caused the alleged wrong, the tie of each party to one or more states, and the location of the parties' dealings. ${ }^{24}$

A court considering a claim that a telephone conversation has been surreptitiously taped in violation of a statute, or that information from an illegally taped telephone conversation was disclosed, might apply section $152 .{ }^{25}$ Section 152 provides:

In an action for an invasion of a right of privacy, the local law of the state where the invasion occurred determines the rights and liabilities of the parties, except as stated in $\S 153$, unless, with respect to the particular issue, some other state has a more significant relationship under the principles stated in $\S$ 6 to the occurrence and the parties, in which event the local law of the other state will be applied. ${ }^{26}$

Comment $\mathrm{c}$ to section 152 helps determine the location of the invasion. Comment c states:

Place of invasion. When the invasion involves an intrusion upon the plaintiff's solitude, the place of the invasion is the place where the plaintiff was at the

20. Id. Under section 378 of the Restatement (First), "[t] he law of the place of wrong determines whether a person has sustained a legal injury." Id.

21. Symeonides, Choice of Law Revolution, supra note 17, at 11.

22. Restatement (Second) of Conflict of Laws $§ 6$ (1971).

23. $I d$.

24. Restatement (Second) of Conflict of Laws § 145 (1971).

25. See infra notes 64-67, 60-71, 117-19, 121, 123-24, 135-39, 141-43 and accompanying text (discussing how courts in Connecticut, New York and Texas used this section to decide cases involving surreptitious taping of interstate telephone conversations).

26. Restatement (Second) of Conflict of Laws § 152 (1971). 
time. When the invasion involves the publication of information about the plaintiff, or the appropriation of his name or likeness, the place of the invasion is where the complained-of matter was communicated to a person other than the plaintiff. ${ }^{27}$

Comment $\mathrm{f}$ of section 152 deals with the situation in which the invasion of privacy and the defendant's conduct occur in different states-when two states are involved, the state in which the invasion occurred is often the state whose law controls because the location of the invasion is generally easy to determine, and the defendant should usually not be allowed to escape the consequences of the defendant's action. ${ }^{28}$ Although the greatest number of states follow the Second Restatement approach, it has been criticized as "too much of a compromise among conflicting philosophies, too vague, exceedingly elastic, unpredictable, directionless, and rudderless." ${ }^{29}$

Under the significant contacts approach, the forum considers the significant relationships among the various states, the alleged wrong, and the parties-much as a court following the Second Restatement approach would apply section 145 of the Second Restatement. ${ }^{30}$

Under the interest analysis approach, the forum considers the governmental interests of the states potentially tied to the subject matter of the lawsuit-much as a court following the Second Restatement approach would apply section 6 of the Second Restatement. California, one of the states using the interest analysis approach, uses a three step process: first, a court determines whether there is a difference between the law of the affected states; second, the court analyzes the states' laws in light of applicable facts to determine if a true conflict exists; and third, the court decides which state's law would be more seriously impaired if the other state's law were applied, and the court then applies the law of the state that would be more seriously impaired. ${ }^{31}$

Under the lex fori approach, a court follows the law of the forum state except where there is an overriding reason to apply the law of another state. ${ }^{32}$ If the nonforum state is the interested state, this would be an overriding reason to apply the law of the non-forum state. A true conflict is one in which the forum state and another state are both interested in the controversy. With a true conflict, the court of the forum state would apply the law of the forum state. ${ }^{33}$

27. Restatement (Second) of Conflict of Laws $§ 152 \mathrm{cmt}$ c (1971).

28. Restatement (Second) of Conflict of Laws $§ 152 \mathrm{cmt} . \mathrm{f}(1971)$.

29. Symeon C. Symeonides, The Judicial Acceptance of the Second Conflicts Restatement: A Mixed Blessing, 56 MD. L. Rev. 1248, 1250 (1997) [hereinafter Symeonides, Mixed Blessing].

30. See Symeonides, Choice of Law Revolution, supra note 17, at 33, 98-99.

31. Kearney v. Salomon Smith Barney, Inc., 137 P.3d 914, 922 (Cal. 2006). For a discussion of Kearney, see infra notes 56-63 and accompanying text.

32. See Symeonides, Choice of Law Revolution, supra note 17, at 76-81.

33. See id. 
Under the better law approach, a court begins by considering the location of the injury (i.e., lex loci delicti), and then considers five factors: "predictability of results," "maintenance of interstate and international order," "simplification of the judicial task," "advancement of the forum's governmental interests," and "application of the better rule of law." ${ }^{4}$

As the name indicates, the six states following the combined modern approach fashion their own method for dealing with tort conflict of law cases by choosing from the several conflict of law approaches. Hawaii draws on the interest analysis, the Second Restatement and the five factors of the better law approaches. ${ }^{35}$ Massachusetts ${ }^{36}$ and New Jersey ${ }^{37}$ draw on the interest analysis and the Second Restatement approaches. As judged by the 2006 New York case discussed later in this paper, New York seems to use the traditional, interest analysis and the Second Restatement approaches. ${ }^{38}$ North Dakota draws on the significant contacts and the five factors of the better law approach. ${ }^{39}$ Oregon draws on the interest analysis and the Second Restatement approaches, but with an emphasis on the law of the forum. ${ }^{40}$ As judged by the three wiretapping cases discussed later in this paper, it is unclear which method Pennsylvania uses for dealing with tort conflict of law cases. ${ }^{41}$ Of the three cases, the 1992 case seemed to be decided following the traditional approach, the 2000 case was decided using the interest analysis approach, and the 2005 case was decided under the Second Restatement. ${ }^{42}$

When reviewing surreptitious interstate wiretapping cases, it is interesting to consider whether a state has followed the announced conflict of law approach of the state. The following section describes cases decided using conflict of law rules and compares the approach the courts used with the state's announced conflict of law approach.

\section{HAVE THE COURTS FOLLOWED THE CONFLICT OF LAW APPROACHES OF THEIR VARIOUS STATES?}

It is sometimes difficult to classify the conflict of law approach of a particular state, especially when some states lack recent case law discussing conflict of law. ${ }^{43}$

34. Schubert v. Target Stores, Inc., 201 S.W.3d 917, 921 (Ark. 2005).

35. See Symeonides, Choice of Law Revolution, supra note 17, at 116.

36. Id. at 115 .

37. Earl M. Maltz, Do Modern Theories of Conflict of Laws Work? The New Jersey Experience, 36 Rutgers L.J. 527, 541-42 (2005).

38. See infra notes $117-19,121,123-24$ and accompanying text.

39. Daley v. American States Preferred Ins. Co., 587 N.W.2d 159, 160-66 (N.D. 1998).

40. See Symeonides, Choice of Law Revolution, supra note 17, at 115-16.

41. See infra notes $125-30,132-34$ and accompanying text.

42. Id.

43. Symeonides, Mixed Blessing, supra note 29, at 1261-62. 
Also, some courts choose to analyze a surreptitious interstate wiretapping case by determining whether the exclusionary rule applies rather than analyzing the case from a conflict of law perspective. ${ }^{44}$

As one might imagine, some courts do follow the announced conflict of law approach of the state while some do not. As explained in this section, California, ${ }^{45}$ Connecticut, ${ }^{46}$ Massachusetts federal court, ${ }^{47}$ New York, ${ }^{48}$ and Texas ${ }^{49}$ applied the conflict of law approach identified by Symeonides when deciding cases concerning surreptitious taping of an interstate telephone conversation, ${ }^{50}$ but Florida, ${ }^{51}$ Massachusetts state court, ${ }^{52}$ New Hampshire, ${ }^{53}$ Pennsylvania, ${ }^{54}$ and Washington ${ }^{55}$ did not.

\section{A. California}

In 2006, the California Supreme Court decided Kearney v. Salomon Smith Barney, Inc., a case in which Georgia brokers surreptitiously taped telephone conversations with California residents Kearney and Levy. ${ }^{56}$ Kearney and Levy sued Salomon Smith Barney under the California statute that prohibits secretly recording a telephone conversation without the consent of all parties and requested injunctive relief and damages or restitution. ${ }^{57}$

44. See infra notes $172-87$ and accompanying text. For example, in a criminal case involving surreptitious interstate wiretapping, an Oregon intermediate appellate court recognized that the defendant wanted the court to use a conflict of law approach for the issue of whether a telephone conversation should be suppressed, which the court refused to do. State v. Fleming, 755 P.2d 725, 727 (Or. Ct. App. 1988).

45. See infra notes $56-63$ and accompanying text.

46. See infra notes $64-71$ and accompanying text.

47. See infra notes $106-12$ and accompanying text.

48. See infra notes 117-19, 121, 123-24 and accompanying text.

49. See infra notes $135-43$ and accompanying text.

50. See supra note 18 and accompanying text.

51. See infra notes $72-97$ and accompanying text.

52. See infra notes $98-105$ and accompanying text.

53. See infra notes $113-16$ and accompanying text.

54. See infra notes 125-34 and accompanying text.

55. See infra notes $144-55$ and accompanying text.

56. 137 P.3d 914 (Cal. 2006). There was no discussion in the case of the reason for the taping, perhaps because the trial court dismissed the complaint after sustaining Salomon Smith Barney's demurrer. Id. at 918 . One reason for the taping might be to demonstrate compliance with regulations affecting brokers, and the Kearney plaintiffs learned of the surreptitious taping after filing a complaint against Salomon Smith Barney with the National Association of Securities Dealers (NASD), alleging “'malfeasance, fraud, and breach of fiduciary duties' in providing advice to them." Id. The National Association of Securities Dealers rule 3010 requires those firms with a significant number of brokers previously employed by firms disciplined by NASD to tape all telephone conversations. $I d$. at $921 \mathrm{n} .3$. Salomon Smith Barney, however, was not subject to rule 3010. Id.

57. Id. at 917 . 
Employing the governmental interest analysis, the court found a conflict between California's and Georgia's interests in the laws of their respective states. ${ }^{58}$ The court decided that the privacy of California residents would be negatively impacted if Georgia law (one party consent) was applied, and further, that applying Georgia law would put California businesses at a disadvantage, while the requirement that a Georgia caller inform the California resident that the conversation was being recorded was very light. ${ }^{59}$ Because the law had been unclear prior to Kearney, the court did not allow money damages for past conduct because of Georgia's interest in protecting those who might have secretly taped telephone conversations in the past in reliance on Georgia law. ${ }^{60}$

The California Supreme Court noted that the lower courts feared a legalistic "gotcha" if a California resident was able to sue the resident of a one-party consent state for surreptitiously taping a telephone conversation with a California resident in California and to recover money damages. ${ }^{61}$ The legalistic "gotcha" concept apparently stems from the fact that a small minority of states require all-party consent to tape a telephone conversation while an overwhelming majority of the states allow surreptitious taping of a telephone conversation on the consent of one party to the conversation. In the Kearney civil law context, the California Supreme Court specifically limited its analysis to the Kearney facts, which involved a series of surreptitious tapings by a business, and where there was no allegation that the taping was done to gather evidence of criminal or tortious conduct. ${ }^{62}$ The California Supreme Court recognized that the penal portion of the statute could arguably apply to someone surreptitiously taping a conversation from outside California, but the court refused to speculate whether a criminal prosecution under the California wiretapping statute would pass constitutional muster. ${ }^{63}$

\title{
B. Connecticut
}

In 2002, in Lord $v$. Lord, ${ }^{64}$ the Connecticut Superior Court decided a case between former spouses in which the former husband, a Connecticut resident, filed a complaint against the former wife for breach of their separation agreement and for allegedly surreptitiously recording their conversations. Apparently, the former wife taped most of the telephone conversations while she was in New York (one-party consent) and may have taped some other conversations while she was in Connecticut

\author{
58. Id. \\ 59. Id. at $917-18$. \\ 60. $I d$. \\ 61. Id. at 919 . \\ 62. Id. at 939 \\ 63. Id. at 928 . \\ 64. No. CV010380279, 2002 WL 31125621 (Conn. Super. Ct. Aug. 20, 2002).
}


(all-party consent). ${ }^{65}$ Meanwhile, the former husband was in Connecticut when the former wife allegedly taped his telephone conversations. ${ }^{66}$

The court first considered section 152 of the Second Restatement and determined that the former husband's privacy was invaded in Connecticut. ${ }^{67}$ The Lord court then considered the seven factors of section 6 of the Second Restatement: ${ }^{68}$ the court found that (1) Connecticut had an interest in protecting the privacy of telephone conversations, (2) New York had declined to extend this protection, (3) it would not be unfair to apply Connecticut law to the former wife because she intentionally taped the telephone calls that she made into Connecticut, and (4) applying New York law would encourage forum shopping. ${ }^{69}$ The court held that Connecticut law would apply because Connecticut had the more significant relationship to the case, and New York did not have a greater interest in having its law apply. ${ }^{70}$ Therefore, the court denied the former wife's motion for summary judgment. ${ }^{71}$

\section{Florida}

Florida generally applies the Second Restatement approach. In cases from 2004 and 1998, however, Florida intermediate appellate courts ${ }^{72}$ said that there could be no cause of action unless the words that were surreptitiously taped originated in Florida. ${ }^{73}$ The courts provided no further conflict of law analysis even though both cases involved at least two states. In other words, according to those two cases, for purposes of applying Florida wiretapping law, the interception occurs where the words that were surreptitiously taped were spoken. Applying that line of reasoning would mean that a resident of a one-party consent state could not hold someone liable under Florida law for surreptitiously taping a telephone call even if the person doing the taping was in Florida. Something analogous to that occurred in the 2007 case discussed below.

65. See id. at *5.

66. Id. at * 1 , *4. See infra note 172 . The court recognized that there was a 1997 criminal case concerning surreptitious taping of a telephone conversation and whether Connecticut or New York law applied. See State v. Vincente, 688 A.2d 359 (Conn. App. Ct. 1997). The Lord court distinguished Vincente as a criminal case concerning a motion to suppress and involving distinct Connecticut statutes. Lord, 2002 WL 31125621 , at $* 5$ n. 5 .

67. Id. at *1, *4. See supra notes 26-28 and accompanying text.

68. See supra notes $22-23$ and accompanying text.

69. Lord, 2002 WL 31125621, at *6-7.

70. Id. at $* 8$.

71. Id.

72. Cohen Brothers, LLC v. ME Corp., S.A., 872 So. 2d 321, 324 (Fla. Dist. Ct. App. 2004); Koch v. Kimball, 710 So. 2d 5, 7 (Fla. Dist. Ct. App. 1998).

73. See infra notes 75-84 and accompanying text. See also infra notes 190-205 and accompanying text for a different interpretation of the term "intercept." 
To make matters even more confusing, another line of Florida cases states that the interception occurs either where the words are spoken, or where the taping occurs. ${ }^{74}$ This line of cases is discussed later in the paper.

In 2004, a Florida intermediate appellate court decided Cohen Brothers, $L L C$ v. $M E$ Corp. ${ }^{75}$ The case involved a telephone conference call with at least six participants, all members of the Deltom Solutions, LLC management committee, who were located in Argentina, Florida, New York, and Puerto Rico. The Rosconis, then located in Argentina, secretly recorded the telephone conference call. During the call, two individuals (at least one of whom was Deltom's attorney) were in Miami (where the call originated), one individual was in New York, and the other individual was in Puerto Rico. ${ }^{76}$

The Cohen court stated that because the Florida wiretap statute requires either that a plaintiff be a Florida citizen or that the interception occur in Florida, the trial court correctly dismissed the lawsuit. ${ }^{77}$ Even though two conference call participants were located in Florida, the Miami attorneys were not parties to the lawsuit, and there was no allegation that their conversation was wrongly intercepted. The plaintiff, Cohen Bros., a New York corporation, was not a Florida resident. ${ }^{78}$ Thus, the court affirmed the dismissal of the suit. ${ }^{79}$

In 1998, a Florida intermediate appellate court decided Koch v. Kimball. ${ }^{80}$ Koch was an insurance salesperson who lived in Georgia (one-party consent). Because her sales territory included Florida (all-party consent), she made frequent trips there. As part of her job, Koch called Kimball-Koch's supervisor who lived in Tampa, Florida-weekly. On April 24, 1996, Koch, then at home in Georgia, called Kimball, then at home in Florida, and surreptitiously taped the telephone conversation. Kimball sued Koch in Florida state court under the Florida wiretapping statute for secretly taping the telephone conversation. ${ }^{81}$

The Koch court found that the interception occurred in Florida because Kimball was located in Tampa, Florida when Koch surreptitiously taped the telephone conversation. ${ }^{82}$ Therefore, the intermediate appellate court held that the trial court correctly refused to dismiss Kimball's lawsuit. ${ }^{83}$ The Koch court equated interception

74. See infra notes $190-205$ and accompanying text.

75. Cohen, 872 So. 2d 321. See infra notes 190-93 and accompanying text for further discussion of Cohen.

76. Cohen, 872 So. 2 d at $322-23$.

77. Id. at 323 .

78. Id. at 324 .

79. Id. at 325 .

80. 710 So. 2d 5. See infra notes 190-93 and accompanying text for further discussion of Cohen. See also infra notes 161-64 and accompanying text for discussion of a 2008 case that limited the extra-territorial effect of Cohen.

81. Koch, 710 So. $2 \mathrm{~d}$ at 6 .

82. Id. at 7 .

83. Id. 
with the location where the surreptitiously taped telephone conversation originated: " $[\mathrm{T}]$ he interception occurs where the words or the communication is uttered, not where it is recorded or heard." 84

It is interesting to note that the Koch court presumably would have arrived at the same result had the court applied the Second Restatement, which Symeonides identified as the conflict of law approach followed in the state. Although Koch taped the conversation while in Georgia, Kimball was located in Florida, Koch visited Florida on a very regular basis and called Kimball there weekly, their relationship was centered in Florida, and because it is an all-party consent state, Florida has a strong interest in protecting against a conversation being taped with less than allparty consent. Thus, under section 145 of the Second Restatement, the court probably would have held that most of Koch's and Kimball's significant contacts were with Florida. In addition, section 152 would influence the court to determine that Kimball's privacy was invaded in Florida. Under section 6 of the Second Restatement, the court would recognize that there is a conflict between Georgia and Florida law, but that Florida's public policy of prohibiting the taping of telephone conversations with less than all-party consent should be honored. Allowing Koch to escape application of the Florida statute would encourage surreptitious taping in a future case with similar facts in which the surreptitious taping of a conversation occurred in a one-party consent state.

In 2007, in Leff v. First Horizon Home Loan ${ }^{85}$ a federal district court sitting in New Jersey in a diversity case ruled that a surreptitiously-taped telephone call was not inadmissible under Florida law even though Leff, a New Jersey resident, apparently surreptitiously taped the telephone call he made to Bergida in New Jersey while traveling in Florida. ${ }^{86}$ Following Koch, the court held that the conversation could not be suppressed under Florida law because Bergida was not a Florida resident, nor was the conversation intercepted in Florida. ${ }^{87}$ The conversation would also not be suppressed under New Jersey law because New Jersey is a one-party consent state, allowing a participant in the conversation to tape the conversation so long as the taping is made for other than a criminal or tortious purpose..$^{88}$

One might wonder what the Leff and Cohen courts would have done had they applied announced conflict of law principles. In Leff, the forum was New Jersey, with the federal district court deciding a diversity of citizenship case. ${ }^{89}$ If the court had directly discussed conflict of law, it probably would have followed New Jersey

84. Id. In arriving at this interpretation of interception, the Koch court relied on State v. Mozo, 655 So. $2 \mathrm{~d}$ 1115, 1117 (Fla. 1995), a case involving the taping of a cordless telephone conversation. Koch, 710 So. $2 \mathrm{~d}$ at 7. See infra notes 194-98 and accompanying text for a discussion of Mozo.

85. No. 05-3648, 2007 WL 2572362 (D.N.J. Sept. 4, 2007).

86. Id. at *4-6.

87. Id. at *4-5.

88. Id. at ${ }^{*} 4-6$.

89. Leff, 2007 WL 2572362. 
conflict of law principles because New Jersey was the forum. New Jersey applies the interest analysis approach; therefore, the court likely would have found that New Jersey has the greater interest in the controversy and New Jersey allows taping upon one-party consent. Thus, New Jersey has an interest in protecting a telephone conversation against a non-participant recording, but under state law, one has to evaluate with whom one is speaking because a party to the conversation can talk about or play the tape of the conversation later. In addition, Leff and Bergida had a business, not a personal, relationship, so Bergida should have known that their telephone conversation would be taped. Except for the circumstance of Leff traveling in Florida at the time of the taping, all of the ties were with New Jersey rather than Florida. Thus, the Leff court probably would have reached the same result-that the taped conversation should not be suppressed-had the federal court applied New Jersey conflict of law principles.

Cohen is an interesting case in that the court used a very mechanical approach, stating that the Florida wiretapping statutes were inapplicable because none of the plaintiffs were Florida residents, nor was there any allegation that anyone whose conversation had been surreptitiously taped complained of the taping. ${ }^{90}$ First of all, it is unclear where the court found the Florida resident basis for a lawsuit. This basis for the lawsuit had not been stated in any prior case interpreting the Florida wiretapping statutes. ${ }^{91}$ Also, as explained below, there are two different lines of reasoning in Florida wiretapping cases as to the location of the interception. ${ }^{92}$ The Cohen court followed the Koch line of reasoning, which ties interception to the location where the words originate rather than the location of the taping. ${ }^{93}$

Cohen Bros. and Deltom were both plaintiffs in the lawsuit. ${ }^{94}$ Cohen Bros. had its principal place of business in Miami, and Deltom's attorney, who was located in Miami, initiated the telephone conference. Thus, the court could have found either that Cohen Bros. was a Florida resident or that Deltom, through its Miami attorney, complained of the taping, had the court wanted to, and the court might not have had to dismiss the lawsuit. There still may have been a problem obtaining Florida jurisdiction over the Rosconis as it is unclear from the facts what ties they had, if any, to Florida.

Note that the Cohen court incorrectly considered the expectation of privacy in analyzing the taping of a telephone conversation. ${ }^{95}$ Under Florida law, parties to a telephone conversation do not have to have any expectation of privacy for the conversation to be protected as a wire communication. ${ }^{96}$ For a face-to-face conversation

\footnotetext{
90. Cohen, 872 So. $2 \mathrm{~d}$ at 324 .

91. See infra notes $173,190-205$ and accompanying text.

92. See infra notes 190-205 and accompanying text.

93. Cohen, 872 So. $2 \mathrm{~d}$ at 324 .

94. Id. at 323 .

95. See id. at 324 .

96. See Fla. Stat. § 934.02(1) (2008).
} 
to be protected as an oral communication, however, the parties must have an expectation of privacy, and the expectation must be reasonable. ${ }^{97}$

Had the Cohen court applied the Second Restatement approach, it is unclear whether the result would have been different. The parties to the lawsuit were from at least four different jurisdictions, New York, Florida, Argentina and Puerto Rico, and it is unclear whether the Rosconis had the requisite contacts with Florida to avoid Constitutional due process concerns, which might arise should a Florida court analyze whether it could hold Argentinian residents liable under Florida law when the taping occurred in Argentina.

\section{Massachusetts}

In contrast to all but two other cases in this section, Commonwealth v. Gonzalez ${ }^{98}$ was a criminal case coming before the court on Gonzalez's motion to suppress the telephone conversation between Gonzalez, located in Massachusetts (all-party consent), and Gonzalez's one-time friend, Penniman, whose home was in New Hampshire (all-party consent). Prior to Gonzalez's arrest, he called Penniman, but Penniman did not answer immediately. Rather, a computer-generated message began, and Gonzalez's and Penniman's conversation was recorded on Penniman's telephone service. Penniman retrieved the recorded conversation and subsequently notified the Massachusetts State Police about the contents of the tape. ${ }^{99}$

Although Gonzalez was a criminal case, the court stated that in civil cases a Massachusetts court would apply the law of the state with the most significant relationship to the underlying incident and the parties. ${ }^{100}$ However, because this was a criminal prosecution, the court looked at the facts underlying the criminal charges rather than the facts underlying the surreptitious taping. ${ }^{101}$ The court found that under this approach, Massachusetts law would apply because Gonzalez and the victim resided in Massachusetts, the alleged crime occurred in Massachusetts, and Gonzalez was being prosecuted in Massachusetts. ${ }^{102}$ The court denied Gonzalez's motion to suppress the surreptitiously taped telephone conversation because the police were not involved in taping the conversation. ${ }^{103}$

Symeonides identified Massachusetts as a state following the combined modern approach, with the state using the interest analysis and the Second Restatement. ${ }^{104}$ In determining that Massachusetts law applied, however, the Gonzalez court seemed to

97. Cohen, 872 So. 2d at 324-25. See Bast, supra note 14, at 872-74.

98. No. Cr.A.2002-1445, 2004 WL 503959 (Mass. Super. Ct. Mar. 8, 2004). See infra note 176 for further discussion of this case.

99. Id. at ${ }^{*} 1$.

100. Id. at $* 2$.

101. Id.

102. Id.

103. Id. at *3.

104. Symeonides, Choice of Law Revolution, supra note 17 , at 115. 
use the significant contacts approach rather than the combined modern approach, although the resulting application of Massachusetts law probably would have been the same whether using the significant contacts approach or the combined modern approach. After determining that Massachusetts law applied, the court then seemed reluctant to apply the Massachusetts wiretap statutes. Although the court could have found that Penniman's taping was either intentional or unintentional, because Penniman's telephone service automatically taped the conversation, a finding that the taping was intentional would have made a vital piece of evidence inadmissible and could have subjected Penniman to civil or criminal liability. Instead, the Gonzalez court decided that the telephone conversation should not be suppressed under the general exclusionary rule. ${ }^{105}$

The United States District Court for the District of Massachusetts decided two cases, each of which involved a surreptitiously taped conversation where the conversation was taped outside Massachusetts, and the non-consenting party to the conversation was located in Massachusetts. In the 1999 case, MacNeill Engineering Co., Inc. v. Trisport, Ltd., ${ }^{106}$ MacNeill wanted to amend its complaint to add the president of MacNeill as a plaintiff and to add the claim that Trisport's agent in England surreptitiously taped a telephone conversation with MacNeill's president while the president was in Massachusetts. ${ }^{107}$ In the 1986 case, Pendell v. AMS/Oil, Inc., ${ }^{108}$ Smith, one of the plaintiffs, was at home in Massachusetts when an AMS agent, located in Rhode Island, surreptitiously taped their conversation. ${ }^{109}$

In refusing to allow MacNeill to amend its complaint, the MacNeill court relied heavily on the opinion in Pendell, ${ }^{110}$ in which the Pendell court had granted partial summary judgment in favor of the defendant on the illegal wiretapping claim. The courts recognized that Massachusetts follows the combined modern approach, looking to the Second Restatement and the interest analysis approaches. ${ }^{111}$ The Pendell court decided that Rhode Island law should apply because the taping, the last action to occur, took place in Rhode Island, the Rhode Island resident who did the taping could have reasonably thought that Rhode Island law would apply, the Massachusetts wiretapping statute requiring all-party consent was in the nature of a local statute, there was no wording in the Massachusetts statute indicating that the statute was to have effect outside of Massachusetts, and the court applying Rhode Island law would protect privacy, although not to as great an extent as Massachusetts law. ${ }^{112}$

105. See infra note 176 and accompanying text.

106. 59 F. Supp. 2d 199 (D. Mass. 1999).

107. Id. at 200, 202.

108. No. 84-4108-N, 1986 WL 5286 (D. Mass. Apr. 30, 1986).

109. Id. at ${ }^{*} 1$.

110. MacNeill, 59 F. Supp. 2d at 202.

111. Pendell, 1986 WL 5286, at*2-3; MacNeill, 59 F. Supp. 2d at 202.

112. Pendell, 1986 WL 5286, at *3-5. 


\section{E. New Hampshire}

In State v. Windhurst, ${ }^{113}$ Windhurst, accused of murder, filed a motion to suppress telephone conversations between him, while in New Hampshire (all-party consent), and the victim's step-daughter, Melanie Cooper, while in Idaho (one-party consent). Cooper consented to having her telephone conversations taped by New Hampshire police officers and the officers obtained the prior authorization required under New Hampshire law to do so. ${ }^{114}$

The court proceeded to decide the motion in reference to the exclusionary rule and three conflict of law approaches: law of forum state, significant relationship, and governmental interest. ${ }^{115}$ Applying New Hampshire law, the court denied the motion to suppress the surreptitiously taped telephone conversation. ${ }^{116}$ It is interesting that, even though Symeonides identified New Hampshire as a state following the better law approach, that was not one of the three conflict of law approaches discussed by the court. In any event, had the court followed the better law approach, the result would have probably been no different. Neither New Hampshire nor Idaho had any real interest in suppressing the surreptitiously taped telephone conversation. The police followed the requisite procedures of New Hampshire, the all-party consent state, for taping the telephone conversation, and Idaho protects the privacy of telephone calls only to the extent of prohibiting surreptitious taping on less than oneparty consent.

\section{F. New York}

In Locke v. Aston, ${ }^{117}$ Locke, a California resident, and Aston, a New York resident, engaged in telephone negotiations for two years concerning writing a book together, with Locke surreptitiously taping the conversations. After Locke sued Aston in New York state court over the failed book deal, Aston learned that Locke had recorded the telephone calls and filed a counterclaim under the California wiretapping statutes that require all-party consent prior to taping. ${ }^{118}$ It is interesting to note that Aston, a New York resident, was attempting to use a California statute in an offensive move to hold a California resident liable for illegal activity that the California resident was engaged in while in California.

The New York court stated that it follows the interest analysis approach, as does California, ${ }^{119}$ but it seemed to analyze the facts and apply conflict of law principles

113. No. 05-S-1749, 2006 WL 2075119 (N.H. Super. Ct. July 13, 2006).

114. Id. at $* 1$.

115. Id. at *3-6.

116. Id. at ${ }^{*} 6$.

117. 814 N.Y.S.2d 38 (N.Y. App. Div. 2006).

118. Id. at 39-40.

119. Id. at 42 . 
much differently than the Kearney court. ${ }^{120}$ The Locke court stated that, when the parties are domiciled in different states, New York choice of law looks at the location of the injury and cited to comment c of section 152 of the Second Restatement as one of the deciding factors in Locke. ${ }^{121}$ As did the Lord court, ${ }^{122}$ the Locke court found that comment $\mathrm{c}$, which ties invasion of privacy to the plaintiff's location, was applicable to the surreptitious taping of a telephone conversation, and further found that the injury occurred in New York because Aston was located in New York at the times Locke surreptitiously taped his telephone calls from California. ${ }^{123}$ The court concluded that New York had the greater interest in the case, especially because the language of the California wiretapping statutes explicitly makes the statutes apply to California residents, and decided that the trial court should not have allowed Aston to amend his counterclaim to request relief under the California statute. ${ }^{124}$

Presumably, Aston could have held Locke liable under California wiretapping statutes if Locke had sued in California. There is no indication why Locke chose to sue in New York rather than in California, but jurisdictional and wiretapping concerns could have swayed Locke to sue in New York-it is unclear whether Aston had any ties with California, other than telephone calls to Locke, and suing in California would have exposed Locke to civil damages and criminal charges.

\section{G. Pennsylvania}

In Broughal v. First Wachovia Corp. ${ }^{125}$ and Larrison v. Larrison, ${ }^{126}$ the courts denied plaintiffs recovery - in Broughal, because Pennsylvania could not impose civil liability on someone who taped a telephone conversation from North Carolina; ${ }^{127}$ and in Larrison because New York had the greater interest in permitting someone in New York to tape a telephone conversation upon one-party consent. ${ }^{128}$ In Ball $v$. Eblig, ${ }^{129}$ the court held that it lacked jurisdiction, but held in the alternative that Texas law, rather than Pennsylvania law, would apply because Texas had the greater interest in allowing the person located in Texas to tape the telephone conversation

120. See supra notes 56-63 and accompanying text.

121. Locke, 814 N.Y.S.2d at 42.

122. See supra notes 64-67, 69-71 and accompanying text.

123. Locke, 814 N.Y.S.2d at 42.

124. Id.

125. 14 Pa. D. \& C.4th 525, 534 (Pa. Com. Pl. 1992).

126. 750 A.2d 895, 899 (Pa. Super. Ct. 2000).

127. Broughal, 14 Pa. D. \& C.4th at 532-33.

128. Larrison, 750 A.2d at 898.

129. 70 Pa. D. \& C.4th 160 (Pa. Com. Pl. 2005), aff'd, 889 A.2d 107 (Pa. Super. Ct. 2005), aff'd sub nom. Heck v. Ehlig, 889 A.2d 122 (Pa. Super. Ct. 2005). 
upon one-party consent. ${ }^{130}$ Although Symeonides classified Pennsylvania as following the combined modern approach, the three Pennsylvania courts that have considered conflict of law principles in relation to surreptitious taping of interstate telephone calls each used a distinct conflict of law approach. ${ }^{131}$ The Broughal court used the traditional approach, ${ }^{132}$ the Larrison court used the interest analysis approach, ${ }^{133}$ and the Ball court used the Second Restatement approach. ${ }^{134}$

Had the three courts used the combined modern approach, the result may or may not have been different. In all three cases, a reader can feel the reluctance of Pennsylvania, a state that imposes liability on less than all-party consent, to hold an "innocent" out-of-state private individual, with minimal ties to Pennsylvania, liable under Pennsylvania law. This feeling echoes the feeling of the Kearney court, which was willing to hold a nationwide business liable under California law, but specifically limited its decision to the Kearney facts and seemed reluctant to extend liability to a private individual with barely minimum ties to California.

\section{H. Texas}

In Becker v. Computer Sciences Corp., ${ }^{135}$ Becker sued Computer Sciences after the company discharged him. After the lawsuit had been filed, Computer Sciences discovered that Becker, its Houston-area representative, had surreptitiously taped a number of his telephone conversations with Computer Sciences employees located in California, and sought to add a counterclaim against Becker for taping the conversations in violation of California law. ${ }^{136}$

The federal court sitting in Texas in a diversity case recognized that it should apply Texas conflict of law principles and that Texas follows the Second Restatement approach. ${ }^{137}$ The court found that section 152 of the Second Restatement would locate the injury in California. ${ }^{138}$ Other significant contacts triggered by section 145 were that Computer Sciences, with its principal place of business in California, does business in Texas, the taping occurred in Texas, and the relationship of the parties was centered in Texas. ${ }^{139}$

130. Ball, 70 Pa. D. \& C.4th at 163-64, 169-70. See infra notes 165-68 and accompanying text for the court's analysis of jurisdiction.

131. See infra notes $133-35$ and accompanying text.

132. See Broughal, 14 Pa. D. \& C.4th at 532-33.

133. Larrison, 750 A.2d at 898.

134. Ball, 70 Pa. D. \& C.4th at $167-69$.

135. 541 F. Supp. 694 (S.D. Tex. 1982).

136. Id. at 697 .

137. $I d$. at 703-04.

138. Id. at 704.

139. Id. 
In considering the seven factors of section 6 of the Second Restatement, ${ }^{140}$ the court found that California had an interest in protecting the privacy of telephone conversations, while Texas allowed taping upon one-party consent, and Becker had relied on the Texas wiretapping statutes when surreptitiously taping the telephone calls. The court found that the policies of California and Texas, in protecting the privacy of telephone conversations were similar and noted that comment $\mathrm{h}$ to section 6 directed the court to apply the law of the forum state when the state policies were the same but the state laws contained "minor differences." 141 The court further found that applying Texas law would be easier and would lead to predictability and uniformity of results. ${ }^{142}$ Therefore, the court held that Texas law would apply because Texas had the more significant relationship to the case, and the court denied Computer Sciences' motion to amend its answer to add a counterclaim. ${ }^{143}$

It is interesting that the federal court quickly and correctly identified the conflict of law approach followed by Texas and then provided a detailed discussion as to how the Second Restatement applied.

\section{Washington}

Washington generally applies the Second Restatement approach. In two cases, however, one from 1992 and one from 2006, the Supreme Court of Washington seemed to apply the traditional approach, focusing on the state in which the telephone conversation was secretly recorded. ${ }^{144}$

In Kadoranian by Peach v. Bellingham Police Dept., ${ }^{145}$ the Bellingham Police Department obtained authorization under the Washington wiretapping statutes to tape a telephone conversation with George Kadoranian, a resident of British Columbia, Canada. The police informant called George Kadoranian's telephone, and the police taped a brief exchange with Alice Kadoranian, George's daughter. ${ }^{146}$

The Washington Supreme Court, without any reference to a conflict of law analysis, held that the surreptitious taping was authorized because the authorization procedure had been followed and the taping occurred in Washington. ${ }^{147}$ The Washington Supreme Court further held that Alice was not entitled to statutory damages for "inadvertent interceptions of inconsequential, non-incriminating conversations and communications so long as the interceptions are accomplished

\footnotetext{
140. Id. at 703. See supra notes 22-23 and accompanying text.

141. Becker, 541 F. Supp. at 704-06.

142. $I d$. at 706.

143. Id.

144. See infra notes $145-54$ and accompanying text.

145. 829 P.2d 1061, 1063 (Wash. 1992).

146. Id. at $1062-63$.

147. Id. at 1064 .
} 
pursuant to valid authorizations; and the communication by Ms. Kadoranian to a stranger inquiring whether her father was at home was not a 'private' communication." ${ }^{148}$

In State v. Fowler, ${ }^{149}$ Fowler's stepdaughter was in Oregon in 2002 when she surreptitiously taped two telephone calls with Fowler at the request of the Oregon State Police while Fowler was located in Washington. The trial court denied Fowler's motion to suppress the two telephone conversations, and Fowler was convicted in Washington state court of several counts of sexual misconduct with the stepdaughter. ${ }^{150}$

Because Oregon is a one-party consent state with regard to telephone conversations, the surreptitious taping was legal in Oregon. ${ }^{151}$ However, taping of a telephone call by a private individual is illegal in Washington without all-party consent. Washington wiretapping statutes, as statutes in most all-party consent states, do permit surreptitious taping of telephone conversations upon one-party consent if the party taping is a police officer or police informant, but Washington requires that this type of taping be authorized in advance by a judge and that the taping is permitted only to gather evidence of a felony. ${ }^{152}$

The court found that because the Oregon taping was legal under Oregon state law, the taped telephone conversations were properly ruled admissible. ${ }^{153}$ The court emphasized that there was no connection between Oregon and Washington authorities concerning the investigation of sexual misconduct charges against Fowler at the time of the taping and that the result would have been different had Oregon authorities acted as agents of the Washington authorities. ${ }^{154}$

Would the result have been different in Kadoranian and Fowler had the Washington courts followed the Second Restatement approach? The courts did consider some of the significant contacts under section 145 of the Second Restatement, noting the location of the parties and the location of the surreptitious taping, which was Washington in Kadoranian and Oregon in Fowler. Had the courts considered section 152 of the Second Restatement, the Kadoranian court would have found that Alice's privacy was violated in Canada, and the Fowler court would have found that Fowler's privacy was violated in Washington. Had the courts followed section 6 of the Second Restatement, they would have had to consider additional factors, among which were the interests of the various jurisdictions. Therefore, by applying the Second Restatement, the court's result in Kadoranian probably would have been the same, but the court's result in Fowler might have been different.

148. Id. at 1068 .

149. 139 P.3d 342 (Wash. 2006).

150. Id. at $343-45$.

151. See Or. Rev. Stat. Ann. § 165.540 (West 2009).

152. See Wash. Rev. Code Ann. §9.73.090 (West 2009).

153. See Fowler, 139 P.3d at 343.

154. See id. at $347-48$. 
In Kadoranian, the police had attempted to obtain the correct authorization. ${ }^{155}$ Even though Alice's privacy had been technically violated, she disclosed nothing personal during the taping. However, in Fowler, Fowler was a Washington resident and made incriminating statements during the conversation. Although Washington has a strong interest in protecting the privacy of its residents, as expressed in the Washington Constitution and the Washington wiretapping statutes, Fowler's conversations were not suppressed.

The Fowler court was in a quandary because it wanted to use the telephone conversations that the alleged sexual misconduct victim taped at the request of the Oregon police, but Fowler was in Washington when his conversations were surreptitiously taped. Perhaps the more principled decision would have been to suppress the conversations because Fowler resided in Washington, his privacy was invaded in Washington, and Washington wiretapping statutes require all-party consent, without regard to the subject matter of the conversation or the identity of the person whose conversation was surreptitiously taped. A number of states have considered cases in which surreptitious taping complied with the law of the state where the taping occurred but did not comply with the law of the forum state, and the authorities in the state where the taping occurred were not agents of the authorities of the forum state. The majority of states considering this type of case have held that when the taping was legal under the laws of the state, the surreptitiously taped conversation is admissible even if it would have otherwise been inadmissible under the forum's wiretapping statutes. ${ }^{156}$ Maryland, for example, is in the minority on this question. ${ }^{157}$ The Fowler decision is thus in line with the majority.

The cases previously discussed in this section are from California, Connecticut, Florida, Massachusetts, New Hampshire, New York, Pennsylvania, Texas, and Washington. Of those nine states, only two-New York and Texas-are one-party consent states. The Massachusetts and New Hampshire cases and one of the cases from Washington are criminal cases, and the rest are civil cases. In the criminal cases, the courts discuss wiretapping statutes because the criminal defendant wants to have a crucial telephone conversation suppressed. In civil cases, wiretapping statutes are discussed because the plaintiff wants to collect damages, the wiretapping claim arose as a counterclaim, or one of the parties seeks to have a taped telephone conversation ruled inadmissible.

In the three criminal cases, Windhurst, Gonzalez, and Fowler, none of the courts suppressed the surreptitiously taped telephone conversations. Windhurst, the New Hampshire case, was an easy case in that the police provided Windhurst the protection afforded under the New Hampshire all-party consent statute, which

155. See Kadoranian, 829 P.2d at 1063.

156. Connecticut, Florida, Hawaii, Illinois, Kentucky, Minnesota, Missouri, Nevada, New Jersey, Oklahoma, Pennsylvania, and Washington are in the majority while Maryland and Montana are in the minority. Clifford S. Fishman \& Anne T. McKenna, Wiretapping \& Eavesdropping: Surveillance in the Internet Age $\$ 14: 19$ (3d Ed. 2008).

157. See infra notes $174-75$. 
required authorization prior to the surreptitious taping-the police took the precaution of obtaining authorization even though the conversation was taped in a one-party consent state that did not require authorization in advance so long as one party to the telephone conversation consented to the taping. Thus, Windhurst's argument that the police should have obtained prior specific authorization to tape outside of New Hampshire, which New Hampshire authorities had no jurisdiction to do, was a very tenuous argument, but the best that Windhurst could formulate given the circumstances.

As explained above in this section, there was sufficient basis under their respective wiretapping statutes for the Gonzalez (Massachusetts) and Fowler (Washington) courts to suppress the taped conversations. Cynics might opine that the Massachusetts and Washington courts reached the right result in not suppressing defendant's incriminating statements. Without this crucial evidence, the defendants might not have been convicted; however, another view is that those decisions created exceptions to the wiretapping statutes of those states.

In civil cases from New York (Locke) and Texas (Becker), one party was located in each of those one-party consent states, and the other party was located in California. In civil cases from California (Kearney), Connecticut (Lord), Florida (Cohen and Koch), and Pennsylvania (Broughal, Larrison and Ball), plaintiffs in all-party consent states whose telephone conversations were surreptitiously taped were attempting to hold individuals in one-party consent states liable for tapings that occurred in oneparty consent states.

Not surprisingly, New York and Texas, both one-party consent states, applied the wiretapping statutes of the forum states, disallowing counterclaims for surreptitious taping. Applying the law of New York, the Locke court denied its resident the possibility of collecting damages against a California resident who had taped in California in violation of California law. Applying the law of Texas, the Becker court denied a California resident the possibility of collecting damages against a Texas resident who had taped in Texas. Although it did not violate the law of the state where the taping occurred, the taping did violate the law of the state of the alleged injury. Thus, because of the facts in the two cases, New York law favored the California resident and precluded the possibility of awarding damages to the New York resident, while Texas law favored the Texas resident, precluding the award of damages against the Texas resident.

Courts in California, Connecticut, Florida, Massachusetts, and Pennsylvania are split as to whether plaintiffs in all-party consent states whose telephone conversations were surreptitiously taped can hold individuals in one-party consent states liable for taping that occurred in one-party consent states. The California, Connecticut, and Florida courts allowed liability to be imposed on someone surreptitiously taping a telephone conversation from a one-party consent state in what some would perceive as a "gotcha" situation, while the Massachusetts and Pennsylvania courts did not. The California and Florida cases involved defendants engaged in business in allparty consent states, and California may or may not extend its ruling to a private individual defendant. In contrast, the Connecticut case involved a domestic dispute. 


\section{COURT ANALYSIS FROM A CONFLICT OF LAW PERSPECTIVE OR FROM ANOTHER PERSPECTIVE}

As discussed above, a court may engage in a conflict of law analysis when faced with a case concerning the surreptitious taping of an interstate telephone conversation. Other issues that might arise are whether a court has jurisdiction over an out-of-state party and whether the taped telephone conversation is inadmissible under an exclusionary rule because the conversation was illegally taped.

\section{A. Jurisdiction}

On a preliminary basis, some courts consider whether an interstate telephone call from a one-party consent state made to an all-party consent state, which is also the forum state, provides the forum with jurisdiction over the person calling from the one-party consent state. Cases from California, Florida, and Pennsylvania dealt with the issue of whether the forum state had jurisdiction over the out-of-state party.

In Kearney, the California case, the defendant Salomon Smith Barney questioned whether the California state court had jurisdiction over it because the lawsuit was grounded on California-Georgia telephone calls surreptitiously recorded by Salomon Smith Barney employees in Georgia. The California Supreme Court quickly disposed of this issue because of the presence of Salomon Smith Barney facilities and operations in California. ${ }^{158}$

In Koch, the earlier of two Florida cases, defendant Koch, a Georgia resident who surreptitiously taped a telephone conversation with her boss located in Florida, questioned whether the Florida state court had jurisdiction over her. The Florida intermediate appellate court quickly disposed of this issue because Koch was a salesperson whose sales territory included Florida, she frequently traveled to Florida, and she called her boss in Tampa, Florida at least once a week. ${ }^{159}$ The Koch court found that Florida did have jurisdiction under Florida's long-arm statute, and Koch had sufficient contacts with Florida such that there was no due process problem with a Florida court deciding the case. ${ }^{160}$

In Kountze v. Kountze, ${ }^{161}$ Neely Kountze secretly taped a telephone conversation with Edward Kountze while Neely was in Nebraska, a one-party consent state, and Edward was in Florida, an all-party consent state. When Edward discovered that his conversation had been secretly taped, he sued Neely, claiming civil damages under the Florida wiretapping statute. ${ }^{162}$ Neely's contacts with Florida included telephone calls and attendance at meetings of less than a day each in 1999 and 2002, with these

158. Kearney, 137 P.3d at 919-20.

159. Koch, 710 So. $2 \mathrm{~d}$ at 6.

160. Id. at 6-7.

161. 996 So. 2d 246 (Fla. Dist. Ct. App. 2008) (en banc).

162. Id. at $247-48$. 
two trips to Florida extending into week-long vacations. ${ }^{163}$ The court distinguished the Kountze facts from the Koch facts and concluded that Florida lacked personal jurisdiction over Neely under the long-arm statute. ${ }^{164}$

In Ball, the Pennsylvania case, the lack of jurisdiction was fatal to the plaintiffs' case, which had been filed in Pennsylvania, an all-party consent state. ${ }^{165}$ The individual plaintiffs and their company were located in Pennsylvania, while the individual defendants and their company were located in Texas. ${ }^{166}$ The Texas defendant company served as a sales representative for the Pennsylvania company for five years in return for commission payments. ${ }^{167}$ The contact during that time period between the two companies was only by email and telephone-the defendants did not travel to Pennsylvania and received no products from Pennsylvania. ${ }^{168}$

\section{B. Exclusionary Rule}

Rather than engage in a conflict of law analysis, a court may analyze a case involving a surreptitiously-taped telephone conversation by determining whether the conversation is admissible. If the case is civil, the court will look to the exclusionary rule of the wiretapping statutes to determine whether it applies. ${ }^{169}$ If it is a criminal case, the court may either look to the exclusionary rule of the wiretapping statutes or to the more general exclusionary rule that buttresses the criminal defendant's constitutional rights. ${ }^{170}$

Often there is little discussion of why a court used the exclusionary rule rather than a conflict of law approach to determine whether a surreptitiously taped telephone conversation should be suppressed. In fact, in some cases there seems to be no recognition by the court that the motion to suppress could be considered by applying a conflict of law analysis. One reason may be that some states, like New York, make a distinction between procedural and substantive law and view the issue of whether a

163. Id. at $248-49$.

164. Id. at 249-50. Both Koch and Kountze were decided by the Florida Second District Court of Appeal, with Koch a panel decision and Kountze an en banc decision. In Kountze, the court took the opportunity to explicitly "recede" from Koch. $I d$. at 247. "[W]e now conclude that a Florida statute that creates a private cause of action for the nonconsensual interception of a communication originating within Florida cannot transform a defendant's out-of-state act of recording that communication, standing alone, into a 'tortious act within this state' for jurisdictional purposes.” Id. at 248. In dicta, the court indicated that a telephone call might provide a Florida court with personal jurisdiction over an out-of-state defendant if the communication was "defamatory, fraudulent, or otherwise an element of a traditional intentional tort under the common law." Id.

165. Ball, 70 Pa. D. \& C.4th at 163-66.

166. Id. at 162 .

167. Id. at 166 .

168. Id.

169. See supra notes $12,14,16$.

170. See supra notes 104-05, 115-16. 
surreptitiously taped telephone conversation should be suppressed as procedural. ${ }^{171}$ In dealing with procedure, conflict of law principles direct the court to apply the law of the forum. In dealing with substantive laws, however, a state may theoretically apply the law of another state, depending on the conflict of law approach of the forum state.

\section{CASES IN WHICH A COURT DETERMINED WHETHER AN EXCLUSIONARY RULE APPLIED}

The cases in this section are from seven states: Connecticut (State v. Vincente ${ }^{172}$ ), Florida (Thompson v. State $\left.{ }^{173}\right)$, Maryland (Perry v. State ${ }^{174}$; Mustafa v. State ${ }^{175}$ ), Massachusetts (Commonwealth v. Gonzalez ${ }^{176}$ ), New Hampshire (Statev. Windhurst ${ }^{177}$ ), New York (I.K. v. M.K. ${ }^{178}$; People v. Capolongo ${ }^{179}$ ), and Oregon (State v. Fleming ${ }^{180}$ ). Five of the seven states, Connecticut, Florida, Maryland, Massachusetts, and New Hampshire, are all-party consent states, and two of the seven states, New York and Oregon, are one-party consent states.

Not surprisingly, because this section concerns the question of whether to exclude a surreptitiously taped telephone conversation, all but one of the cases in this section are criminal cases, with the underlying criminal charges particularly serious in some

171. See, e.g., I.K. v. M.K., 753 N.Y.S.2d 828, 829 (N.Y. Sup. Ct. 2003).

172. 688 A.2d at 362-63 (applying New York law to prison taping by New York state prison officials in assault case). See supra notes 64-71 and accompanying text discussing another Connecticut wiretapping case.

173. Thompson v. State, 731 So. 2d 819, 819-21 (Fla. Dist. Ct. App. 1999) (applying Florida law to affirm trial court's denial of defendant's motion to suppress evidence of a recording obtained by police who had secretly taped a conversation in a case involving sexual battery on a child less than twelve).

174. Perry v. State, 741 A.2d 1162, 1180, 1189 (Md. 1999) (applying Maryland law in a murder-for-hire case to exclude crucial conversation with murderer).

175. Mustafa v. State, 591 A.2d 481, 482-86 (Md. 1991) (applying Maryland law to exclude conversations secretly taped by police informant with drug dealers but not at police request).

176. Gonzalez, 2004 WL 503959, at*2 (applying Massachusetts law to deny motion to suppress surreptitiously taped telephone conversation in murder and intent to commit murder case because of lack of police involvement in taping). See supra notes $98-105$ and accompanying text for further discussion of this case.

177. Windhurst, 2006 WL 2075119, at *2, *5 (applying New Hampshire law in denying motion to suppress telephone conversation taped by New Hampshire police officers in a murder case while in Idaho but with authorization required by New Hampshire law). For further discussion of Windhurst, see supra notes 113-16 and accompanying text.

178. I.K., 753 N.Y.S.2d at 829-30 (applying New York law in a custody dispute, because admissibility of evidence is procedural, to suppress telephone conversation secretly taped without consent of a participant).

179. People v. Capolongo, 85 N.Y.2d 151, 160-64 (1995) (reversing gambling conviction because Capolongo had not received fifteen-day notice required by New York law to introduce conversation wiretapped by Canadian authorities in Canada).

180. Fleming, 755 P.2d at 725-27 (applying Oregon law in a murder, robbery, and burglary case because even though Fleming was in Washington, a police officer in Oregon secretly taped the conversation with consent of a participant in Oregon). 
of the cases. Vincente, the Connecticut case, involved assault; Thompson, the Florida case, involved sexual battery on a child less than twelve; Perry, the later Maryland case, involved a triple murder; Mustafa, the earlier Maryland case, involved illegal drugs; Gonzalez, the Massachusetts case, involved murder; Windhurst, the New Hampshire case, involved a murder; Capolongo, the New York case, involved gambling; and Fleming, the Oregon case, involved murder, robbery and burglary. The police were involved in the taping in Vincente, Thompson, Windhurst, Capolongo (Canadian police), and Fleming. There was no police involvement with the taping in Perry, Mustafa, and Gonzalez.

In each of the criminal cases, except for Capolongo, the court reached a final decision as to whether the surreptitiously taped telephone conversation should be suppressed, with the court refusing to suppress the surreptitiously taped telephone conversation in each case other than the cases from Maryland. The Capolongo court remanded the case, allowing the defendant to file a motion to suppress. ${ }^{181}$

In Vincente, the Connecticut court did not suppress the taped conversation, but the ruling was limited to whether the Connecticut wiretapping statutes, concerning the procedure for police tapings, applied to tapings by New York state authorities in a federal prison in New York state. ${ }^{182}$

As stated above, in a criminal context, Maryland was the only state to rule that a surreptitiously taped interstate telephone conversation should be suppressed. ${ }^{183}$ Maryland was also somewhat of an anomaly in that the surreptitious taping was not illegal in California and the District of Columbia, the jurisdictions in which the taping occurred. As explained above, ${ }^{184}$ Maryland is in the minority of states that would suppress a conversation because the taping was made with less than all-party consent, as required under Maryland law, even though the taping complied with the law of the jurisdiction where the taping occurred. In Perry and Mustafa, the Maryland court of last resort confronted hard cases head-on, but refused to take the easy path of applying the one-party consent law of the jurisdiction in which the telephone conversation was taped. In addition, in Perry, the Maryland court of last resort could have agreed with the lower court that the taping was inadvertent, which would have made the exclusionary rule inapplicable, but the court refused to do so.

In Windhurst, the New Hampshire court did something similar to what the Maryland court had done, in that the New Hampshire court required that the police taping in Idaho comply with New Hampshire wiretapping law. ${ }^{185}$ Even though the court required taping in a one-party consent state to comply with the law of an allparty consent state, the decision was a relatively easy one for the court because the police had obtained the authorization required by New Hampshire law prior to the

181. Capolongo, 85 N.Y.2d at 166. The lower court decision upon remand is unreported.

182. Vincente, 688 A.2d at 362-63.

183. See supra notes $174-75$.

184. See id.

185. See supra notes $113-16,177$. 
taping in Idaho, and thus, the court refused to suppress the surreptitiously taped conversation. One wonders what a New Hampshire court would do if faced with facts such as those in Perry or Mustafa. The court deciding Windhurst was a lower state court, and the result in a surreptitious interstate telephone conversation taping case could differ if decided by the New Hampshire court of last resort.

In Thompson, the Florida court likewise did something similar to what the Maryland and New Hampshire courts had done in that the Florida court required the police taping the telephone conversation in Florida to comply with Florida law. ${ }^{186}$ The police in Thompson, however, easily complied with Florida law because Florida allows a police officer to surreptitiously tape a conversation with no more than oneparty consent and without prior authorization. On the other hand, Illinois requires authorization prior to the police taping upon one-party consent. Thus, the taping in Thompson was not in compliance with Illinois law. Florida, a state that in many instances is very protective of an individual's privacy, paid little attention to the privacy of Thompson, a prior Florida resident. Although not apparent from other interstate wiretapping cases, Florida follows the Second Restatement approach to conflict of law issues. ${ }^{187}$ Under the Second Restatement approach, the result probably would have been the same. Most of the significant contacts, except for Thompson moving to Illinois after the alleged incidents of sexual battery, were with Florida. However, section 152 of the Second Restatement might indicate that Illinois law should be applied because Thompson's privacy was invaded there. Even so, a Florida court probably would have decided that the section 6 factors of the Second Restatement would have guided the court to apply Florida law.

In Gonzalez, the court applied an exception that was apparently available to, but unused by, the Perry court. Both Gonzalez and Perry were cases in which the telephone conversation was surreptitiously recorded on an answering machine. The Gonzalez court decided that the taping was inadvertent, while the Perry court decided that the taping was not inadvertent. In Gonzalez, the parties to the telephone conversation were both located in all-party consent states: Massachusetts and New Hampshire. Thus, without this exception, the telephone conversation would have been suppressed either under Massachusetts or New Hampshire law.

The Fleming reasoning was similar to the reasoning in Perry, Mustafa, Windhurst, and Thompson, in that the Fleming court required the surreptitious taping by the police to comply with the wiretapping law of the forum. As in Windhurst and Thompson, compliance with the law of the forum, Oregon, was painless because Oregon is a oneparty consent state that allows taping upon one-party consent. Thierman, the other prime suspect in the Fleming incident, was presumably easily convinced to allow the police to surreptitiously tape his telephone conversation with Fleming, perhaps hoping to escape a conviction or, if convicted, to receive a lighter sentence.

In reviewing the criminal cases discussed in this section, one could conclude that the Maryland court reached principled decisions in Perry and Mustafa, but one might

186. See supra note 173 and infra note 205 and accompanying text.

187. See supra note 18. 
wonder if the result, particularly in Perry, was just. The suppression of the twentytwo second tape in Perry might mean that a hired killer would go free. Cynics might opine that the Thompson, Gonzalez, and Fleming courts reached the right result by not suppressing defendant's incriminating statements. Without this crucial evidence the defendants might not have been convicted. Another view, however, is that those decisions created exceptions to the wiretapping statutes of those states.

\section{THE VARIABLES IN SURREPTITIOUS INTERSTATE TAPING OF TELEPHONE CONVERSATIONS}

When considering the legality of a surreptitiously taped telephone conversation, one must consider who taped the telephone conversation, the location of the person taping it, the location of the person whose telephone conversation was taped, and the forum state.

For example, it would be important to know whether the person was a private individual or a police officer and whether the person was a party to the conversation. A private individual who is a party to a telephone conversation can surreptitiously tape a conversation in one-party consent states, but may tape the telephone conversation only with the consent of all parties to the conversation in all-party consent states. What if the person taping were a police officer? Generally, a police officer may surreptitiously tape a telephone conversation if the officer is a party to the conversation or a party to the conversation has consented to the taping, but in some all-party consent states, a police officer is prohibited from doing so at all, may be permitted to do so only in certain types of cases, or may be permitted to do so only with prior authorization. ${ }^{188}$ Also, a police officer may surreptitiously tape a telephone conversation, even without any party's consent, pursuant to a court order. In many states the requirements for obtaining a court order are quite detailed, with the procedure for obtaining a court order more difficult to follow than the procedure for obtaining a warrant. The requirements for obtaining a court order differ from state to state; thus, government compliance with the procedure for obtaining a court order in one state may not necessarily mean that the government has complied with the procedure for obtaining a court order in another state.

The state in which the activity is located is important in at least three respects. The legality of the surreptitious taping may be dependent on the state in which the telephone conversation is taped, the state in which the non-consenting party to the telephone conversation is speaking, or the state in which the case is tried, in other words the forum state.

The following are possible locations of the surreptitious taping and the person taped:

1. The surreptitious taping occurred in an all-party consent state and the person taped was located in a one-party consent state.

188. See supra notes 113-16, 149-54, 177 and accompanying text. 
2. The surreptitious taping occurred in a one-party consent state and the person taped was located in an all-party consent state.

3. The surreptitious taping occurred in an all-party consent state and the person taped was located in an all-party consent state.

4. The surreptitious taping occurred in a one-party consent state and the person taped was located in a one-party consent state.

Most of the cases in which conflict of law questions arise involve scenarios 1 and 2 because there is an obvious conflict between the law of a one-party consent state and an all-party consent state. Usually, scenarios 3 and 4 do not involve a conflict of law question because the consent requirement is similar in the two states. However, the facts underlying surreptitious taping cases are not necessarily limited to two states, as illustrated in the following section (the above scenarios do not account for the domiciles of the parties).

The conflict of law approach of the forum state is an additional variable. In any of the above scenarios, the forum could be the state in which the taping occurred, the state in which the person being taped was located, or in a third state. In a few cases, either the surreptitious taping occurred outside the United States or the person taped was located outside the United States and the forum was within the United States. This paper is limited to these scenarios.

\section{A. Location of the Wrong}

In a state that bases its choice of law decisions on the location of the wrong, does the wrong occur where the plaintiff is injured, or where the last event necessary for the wrong occurred? Florida is a state with two conflicting lines of cases concerning the location of the wiretapping tort. ${ }^{189}$

In Cohen, the Florida intermediate appellate court stated that an appropriate plaintiff under Florida's all-party consent wiretapping statute was either a Florida resident or someone whose telephone conversation was surreptitiously taped while that person was located in Florida. ${ }^{190}$ The court stated: "To establish a claim under the Wiretap Statute, the persons bringing suit must be Florida residents or the improper 'interception' must have occurred in Florida." ${ }^{191}$ The Florida wiretap statutes define "intercept" as "the aural or other acquisition of the contents of any wire, electronic, or oral communication through the use of any electronic, mechanical, or other device." ${ }^{192}$ That definition would seem to mean that an interception occurs

189. See supra notes $72-97$ and infra notes $190-205$ and accompanying text.

190. Cohen, 872 So. 2 d at 324.

191. Id. (emphasis added). It is unclear where the court found the Florida resident basis for a lawsuit. Also, the court incorrectly considered the expectation of privacy in analyzing the taping of a telephone conversation.

192. Fla. Stat. § 934.02(3) (2009). 
in the state in which the taping is physically done. However, in Cohen, Florida applied "intercept" to mean the state in which the plaintiff was located when plaintiff's telephone conversation was surreptitiously recorded. According to the Cohen court, "an 'interception' occurs 'where the words or the communication is uttered, not where it is recorded or heard."'193

In deciding Cohen, the Florida Supreme Court relied on a case it decided nine years earlier involving the taping of a cordless telephone conversation. In that case, State v. Mozo, ${ }^{194}$ the court decided that the interception occurs where the words are spoken. ${ }^{195}$ Mozo involved a police officer using a scanner to surreptitiously tape Joyce Mozo's cordless telephone conversation while she was at home. ${ }^{196}$ At the time the conversation was taped, the Florida wiretapping statutes did not explicitly cover cordless telephone conversations. ${ }^{197}$

Because of Florida's traditional interest in privacy, both under the Florida wiretapping statutes and privacy provisions under the Florida Constitution, the Florida Supreme Court struggled to protect Mozo's cordless telephone conversation. The court found that the cordless telephone conversation was protected as an oral communication because Mozo had a reasonable expectation of privacy while speaking in her home. It was in this context that the court stated that the police intercepted the conversation in Mozo's home. ${ }^{198}$

The Mozo court referenced United States $v$. Nelson ${ }^{199}$ in support of its statement that Mozo's telephone call was intercepted where it originated. The Nelson court, however, did not state that a telephone call was intercepted where the words were spoken, but that 'the term 'intercept' as it relates to 'aural acquisitions' refers to the place where a communication is initially obtained regardless of where the communication is ultimately heard." ${ }^{200}$ In Nelson, a Florida judge had authorized wiretapping devices to be placed in Clay County, Florida. Telephone conversations were taped in Clay County and subsequently transmitted to Alachua County, Florida,

193. Cohen, 872 So. $2 \mathrm{~d}$ at 324 (citations omitted).

194. 655 So. 2d 1115 (Fla. 1995).

195. Id. at 1117. "The actual 'interception' of a communication occurs not where such is ultimately heard or recorded but where the communication originates." Id. (citation omitted).

196. Id. at $1115-16$.

197. See Carol M. Bast, Cordless Telephones: If You Can't Say Something Nice, You Might Want to Send a Letter, 32 CRIM. L. Bull. 403 (1996). This was because cordless telephones were a newer technology, and cordless telephone conversations were fairly easy to tape using a scanner purchased in a retail store. $I d$. at 408-09. Prior to 2000, the radio portion of a cordless telephone conversation was explicitly excluded from the definitions of a wire communication and an electronic communication. In 2000, those definitions were amended to remove the exclusion. See 2000 Fla. Laws ch. 2000-369, § 8. Thus, under the present Florida wiretapping statutes, a cordless telephone conversation, if transmitted by analog signal is protected as a wire communication, FLA. STAT. § 934.02(1) (2009), or if transmitted as a digital signal is protected as an electronic communication, FLA. STAT. § 934.02(12) (2009).

198. Mozo, 655 So. $2 \mathrm{~d}$ at 1117.

199. 837 F.2d 1519 (11th Cir. 1988).

200. Id. at 1527 . 
where police officers listened to the conversations. ${ }^{201}$ The Nelson court's interpretation meant that the interception occurred where the calls were taped, and therefore, the Nelson court ruled that the lower court correctly refused to suppress the wiretapped calls. $^{202}$

One Florida intermediate appellate court stated that it would be inappropriate in other wiretapping cases not involving a cordless telephone conversation to limit the term "interception" to the location in which the words were spoken. In 1998, in State v. McCormick, the court stated that interception occurs where the words are spoken and where the conversation is taped. ${ }^{203}$ The issue in that case was whether the court order for a wiretap on a cellular telephone covered the taping of 1,400 calls, where the taping occurred in Melbourne, Florida, or where the suspect was speaking on the cellular telephone, which may have been outside the jurisdiction of the court. Because the McCormick court found that the interception did occur where the calls were taped, the wiretapping was appropriately authorized. ${ }^{204}$ The following year in Thompson v. State, ${ }^{205}$ another intermediate appellate court stated that neither Mozo nor Nelson was applicable to a telephone call between Florida and Illinois, where the Florida police taped the conversation with the permission of the Florida participant.

\section{B. Tort Statutes That Regulate Conduct and Tort Statutes That Allocate Loss}

At least one commentator differentiates between tort statutes that regulate conduct and tort statutes that allocate loss, suggesting that a court should consider violations of conduct-regulating tort statutes differently from violations of lossallocating tort statutes. He hypothesizes that with a conduct-regulating tort statute, the court pays closer attention to the locations of the tort and the resulting injury, whereas a court faced with applying a loss-allocating statute is more cognizant of the parties' ties to other jurisdictions. ${ }^{206}$ Other ties might include the domicile of the parties and the location of their business dealings.

It is interesting to explore this distinction between conduct-regulating and lossallocating statutes to determine if the distinction is helpful to a court attempting to

201. Id. at 1526 .

202. Id. at 1527 .

203. 719 So. 2d 1220, 1222 (Fla. Dist. Ct. App. 1998). “[T]he ‘interception' of a cellular call occurs both at the location of the tapped telephone and at the site where law enforcement authorities hear and record the call. ..." Id.

204. Id. at $1221-23$.

205. 731 So. 2d 819, 820 (Fla. Dist. Ct. App. 1999). For further discussion of this case, see supra note 173.

206. Symeonides, Choice of Law Revolution, supra note 17, at 138. In its 2006 decision concerning surreptitious taping of a Georgia-California telephone conversation, the California Supreme Court provided a fascinating review of several prior California conflict of law cases. See Kearney, 137 P.3d at 922-28. In applying the governmental interest analysis espoused by California, the California Supreme Court, in all but one of the cases, found that the results in those cases seem to demonstrate the hypothesis that the focus will be on the location of the injury under a conduct-regulating statute, while the focus will be on the domicile of the parties under a loss-regulating statute. Id. 
decide a case involving conflict of law and surreptitious taping of telephone conversations. The initial question is whether the wiretapping statutes are conductregulating statutes or loss-allocating statutes. A further question is whether the above hypothesis is proven to be true in decided wiretapping cases.

Wiretapping statutes are generally designed to protect the privacy of a party to a telephone conversation, while allowing the government to gather information in certain circumstances. Wiretapping statutes prohibit surreptitious taping of a telephone conversation unless at least one party consents to the taping. An exception to this prohibition, however, allows the government to surreptitiously tape a telephone conversation after obtaining a court order. Although the requirements to obtain a court order vary by jurisdiction, it is generally much more difficult to obtain a wiretapping court order than to obtain a search warrant. ${ }^{207}$

The individual whose telephone conversation was surreptitiously taped has suffered a loss of privacy at the time of the taping and may suffer an additional loss of privacy if the tape is played or the information from the telephone conversation is used or publicized. Depending on the subject matter of the conversation, the individual whose telephone conversation was surreptitiously taped may suffer an additional loss from the disclosure of secrets discussed during the conversation. An example of an additional loss might be the disclosure of a trade secret or other confidential information, giving someone an advantage the person would not have had, but for the confidential information being disclosed.

Thus, it appears that wiretapping statutes are primarily conduct-regulating in nature, although the availability of a private action to the person whose telephone conversation was taped without the person's consent is loss-allocating in nature. The availability of punitive damages is another indication that the wiretapping statutes are primarily conduct-regulating in nature. ${ }^{208}$

An examination of the civil cases discussed in this paper leads to the conclusion that the wiretapping statutes are primarily conduct-regulating in nature because each decision focused either on the location of the person whose privacy had been invaded (California, Connecticut, and Florida) or the location of the taping (Florida, New York, Pennsylvania, Texas, and Washington).

\section{ANALYSIS}

A typical tort case is one involving an automobile accident with personal injuries and property damage resulting from a driver's negligent failure to comply with traffic ordinances. Surreptitious interception is different than the typical tort case because an invasion of privacy involving the taping of a telephone conversation by a participant in the conversation is only recognized in ten states. And in most of those ten states, taping by a police officer or police informant who is a party to the conversation does not violate state statutes. In thirty-nine states, this conduct is not recognized as a tort.

207. Many government wiretaps have been successfully challenged because of the government's failure to comply with the statutory requirements for obtaining a court order allowing wiretapping.

208. Symeonides, Choice of Law Revolution, supra note 17 at 241. 
With a typical tort case, a state has an interest in the safety, health, and welfare of its citizens. Safeguarding these interests maintains the integrity of the state and promotes its well-being. To keep its residents safe, the state passes conduct-regulating legislation that sets a certain safety standard that one must follow while in the state. This safety standard protects state residents and requires the tortfeasor to pay for injury caused by not following safety standards.

Additionally, a state likes to attract visitors to the state who bring in additional business and help support the state economy. The state must protect the safety of those visitors, or they may not return. State conduct-regulating legislation setting safety standards also applies equally to visitors.

Another typical tort case involves the tortfeasor creating an unsafe condition, which results in physical injury. Surreptitious taping of telephone conversations does not create an unsafe condition because the impact on the victim is usually emotional, although there can be consequential economic damages as well.

In an automobile accident, the location of the accident is clear (unless the accident occurs on the border between states). On the other hand, with surreptitious taping of interstate telephone conversations, it is unclear in which state the crucial conduct occurred. The crucial action could either be the location of the person complaining that the conversation was taped without consent, or the state in which the tape was made. Hence, the underlying events may occur in two states, making surreptitious taping much different from a typical torts analysis. Section 152 of the Second Restatement focuses on the state in which the conversation originated. ${ }^{209} \mathrm{~A}$ number of states, however, focus on the state in which the interception occurred. ${ }^{210}$

One may raise the question of whether the law of the forum is plaintiff-favoring or defendant-favoring. One can speak of the law of an all-party consent state as being plaintiff-favoring, but can one speak of the law of a one-party consent state as defendant favoring?

In a case based on a private cause of action for the surreptitious taping of an interstate telephone conversation, the plaintiff can choose the forum state. One consideration is the ease of filing the lawsuit, with the lawsuit being easier to file and maintain in the state where the plaintiff lives, which is often the state where the plaintiff was located when the conversation was recorded. Another consideration is filing the lawsuit in an all-party consent state having ties to the incident. Thus, a plaintiff who was in a one-party consent state when taped might decide to file the lawsuit in the all-party consent state where the defendant taped the conversation. This state may also be the state in which the defendant resides.

209. See Restatement (Second) of Conflict of Laws $§ 152$ (1971). One line of Florida cases focuses on the state in which the conversation originated. See supra notes 72-94 and accompanying text.

210. Connecticut, New York, Texas, Washington, and a second line of cases in Florida focus on the state in which the interception occurred. See supra notes 64-71 and accompanying text for a discussion of the Connecticut case; notes 117-24 and accompanying text for a discussion of the New York case; notes 135-43 and accompanying text for a discussion of the Texas case; notes 144-54 and accompanying text for a discussion of the Washington cases; and notes 190-205 and accompanying text for a discussion of the second line of Florida cases. 
Imagine that the defendant was in an all-party consent state when surreptitiously taping an interstate telephone conversation. The legal fiction is that one is aware of the law governing the person, and theoretically, one should be more aware of the law of the state in which one acts, particularly if that is the state where one lives. The defendant, however, could have been briefly traveling through the all-party consent state when the defendant made the tape. If the defendant were a resident of the allparty consent state, then the defendant would not have much to justly complain about if the plaintiff filed in the all-party consent state. In an all-party consent state, a resident surreptitiously tapes a telephone conversation at the resident's peril. But with a small minority of states requiring all-party consent, the defendant who surreptitiously tapes a telephone conversation while briefly traveling in the all-party consent state might see this as a "gotcha" situation: when the state regulates conduct in an unanticipated way only to tempt the unsuspecting defendant to violate the statute so that the plaintiff can collect damages.

With an interstate taping case, the feeling is slightly different when the plaintiff was located in an all-party consent state, and the defendant taped the conversation while located in a one-party consent state. The plaintiff will likely file the case in the all-party consent state because of both the ease of maintaining the lawsuit there and the greater likelihood that the forum state will decide the case under the laws of the all-party consent state rather than the laws of the other state. Again, because a small minority of states require all-party consent, the defendant might see this as a "gotcha" situation.

The Kearney court's use of the term "gotcha" is memorable because of the contrast between the colloquial nature of the term and the otherwise formal language of the opinion, together with the associated unfairness and injustice of the children's game. ${ }^{211}$ The unfairness of the "gotcha" situation stems from the fact that the person setting up the scheme ("the schemer") is aware that a reasonable person will fall victim to the scheme only because the victim is unaware of the rules governing it, and the schemer has decided to lay in wait to trap the victim. The situation might not be perceived as unfair, however, if the rules were established out of a safety concern, and the victim should have known about the rules.

A speed trap in a small town that interstate traffic frequents is an example of a gotcha situation. Allegedly, the small town passes an ordinance requiring motorists to slow down when traveling through the town because it is concerned about the safety of town pedestrians and motorists. But the posted speed limit is lower than motorists typically see when passing through similar small towns, and the small town vigorously enforces the speed limit, levying fines for any motorist exceeding the speed limit by even a few miles. The traffic ordinance does protect the safety of town residents, but it may quickly be characterized as a speed trap because of the way in which it is enforced, with the real feeling that the town is more interested in

211. See Scott D. Makar, "Proverbially Speaking": Rotten Apples, Philadelphia Lawyers and Red Cows, 7 U. FLA. J.L. \& Puв. PoL'y 113 (fall 1994-fall 1995). 
raising revenue from unsuspecting tourists than it is in protecting the safety of residents.

Kearney is an example of a case in which a gotcha claim might arise. ${ }^{212}$ The Georgia defendants were located clear across the country from the California plaintiffs. California is often thought of as widely diverging from the rest of the country in many of its practices. Another viewpoint, of course, is to characterize California as a leader, with California testing a new type of legislation that catches on in the rest of the states at some later date. The portrayal of California is important because in Kearney, the Georgia defendants essentially made the claim to the California court that this was a "gotcha" situation in which the court should sympathize with them and not apply the California wiretapping statutes. One would imagine that, had the California plaintiffs filed the case in Georgia, the Georgia court would have applied Georgia law and dismissed the lawsuit. This would be particularly true because the taping occurred in Georgia, with the taping being one of the critical actions that led to potential liability for the Georgia defendants. The Kearney court seemed to struggle with holding the Georgia defendants liable. Instead, the court took the middle ground of issuing an injunction and refusing to impose damages on the Georgia defendants, while announcing that in future cases, California courts would award damages to California residents whose telephone conversations were secretly taped.

The Kearney court probably had no other choice because it wanted to uphold the privacy principle of the California statute and protect its residents, but it sympathized with the plight of the Georgia defendants because this conflict of law issue had not previously been decided. The Kearney court also seemed to be influenced by the fact that the defendants were employees of Salomon Smith Barney, a large brokerage firm with a nationwide business that should have warned its brokers across the nation not to tape telephone calls without all-party consent. ${ }^{213}$ The Kearney court added some curious language at the end of the opinion, which limited the opinion to the facts in the case. ${ }^{214}$ This language might be interpreted to mean that, even after Kearney, a California court might have some leeway to refrain from vigorously applying the California wiretapping statutes to an unsuspecting private individual from a one-party consent state who surreptitiously records a single telephone call

212. See supra notes $56-63$.

213. In fact, Salomon Smith Barney's legal counsel may have been delinquent in not issuing such a warning nationwide.

214. Kearney, 137 P.3d at 939 n.18. The court stated:

[B] ecause this case does not involve the isolated recording of a personal telephone call by an out-of-state individual in a nonbusiness setting, or the recording of a phone call by an out-of-state business that has a reasonable, individualized basis for believing that a particular caller is engaged in criminal or wrongful conduct, we have no occasion to determine how the comparative impairment analysis would apply in those or other comparable settings.

Id. 
with a California resident. The California Supreme Court further noted that this was a civil and not a criminal case.

Of course, the surreptitious taping claim may be among other reasons for filing the lawsuit. In some cases, the surreptitious claim is either filed as a counter-claim, arises after the lawsuit is already filed when one party seeks to make the substance of the telephone conversation inadmissible, or is raised by the criminal defendant in a criminal case. In those types of cases, the forum was not chosen based on the likelihood of the court applying the wiretapping statutes of a particular state, but the forum was chosen for other reasons.

What is the public policy concerning surreptitiously taping telephone calls? What norms do we share concerning whether a party to a telephone conversation should be allowed to surreptitiously tape the conversation? Is it reasonable for an all-party consent wiretapping statute to apply under the particular circumstances? What is the consensus about where the privacy line should be drawn? What if application of the conflict of law approach of the state would cause the state to decide a case in a way that does not seem reasonable based on the particular circumstances? Should a court impose civil liability on an "innocent" individual who surreptitiously taped a telephone conversation? Should a court deciding a criminal case suppress the single piece of evidence that would lead to a murder conviction when the all-party consent statute would cause a surreptitiously taped and incriminating telephone conversation to be inadmissible? Should a court convict an "innocent" individual who surreptitiously taped a telephone conversation?

An overwhelming majority of the states allow taping based on one-party consent. Therefore, many individuals are unaware that taping a telephone conversation may be illegal and may subject them to civil as well as criminal penalties in all-party consent states. Requiring all-party consent may be seen as irrationally overprotective of those plaintiffs from all-party consent states-the proverbial quicksand or pitfall waiting to claim its next victim.

Of course, an all-party consent state like California would characterize its law as superior to the law of one-party consent states because it protects the privacy of its residents, and the state would also characterize the laws of one-party consent states as inferior because the laws of those states fail to protect the privacy of those speaking on the telephone.

A business, especially a business operating nationwide, should be aware of significant differences in the law of the various states that could subject the business to liability. That type of business probably carries insurance to protect it against loss caused by its actions that fly in the face of the law of another state.

Surreptitious taping is much different than the typical tort based on an automobile accident because, in the typical situation, the person taping intends to tape the telephone conversation. The Gonzalez case was an atypical situation in which Penniman did not press the play button prior to taping; however, Penniman's action could still be characterized as intentional because he was speaking on his home telephone and knew that the telephone service automatically recorded the balance of the conversation after the voice mail message started. In Perry, the twenty-two 
second conversation that tied the hit man to the person who had hired the hit man was also automatically recorded on an answering machine. Although the postconviction court found that the taping was inadvertent, the Maryland court of last resort found that the taping was not inadvertent. In contrast, a person involved in an automobile accident does not normally plan to get in an accident, and the accident may be caused by negligence, such as driving too fast for the road conditions.

One of the criteria in the Second Restatement is predictability of results in cases. ${ }^{215} \mathrm{~A}$ negligent tortfeasor may not have tailored his actions to guard against liability imposed in similar situations in decided cases, but one who surreptitiously tapes a telephone call is in a different category. The legal fiction is that we are aware of legal prohibitions. Thus, one who surreptitiously tapes a telephone call does so at that person's peril, especially if the taping is done in an all-party consent state. A court, however, might have sympathy for a defendant who taped a telephone conversation while briefly in an all-party consent state or for a defendant who taped a telephone conversation while in a one-party consent state while the other party to the conversation was in an all-party consent state. After Kearney, a California court would not be loathe to sanction a business operating in California with stiff monetary damages for surreptitiously taping a telephone call, either when the taping occurs in California or the person whose telephone conversation was surreptitiously taped is located in California.

In the criminal context, application of a state wiretapping statute may cause crucial evidence to be excluded. Some cases, like Windhurst, are relatively easy to decide, while other cases, like Thompson, Perry, Mustafa, Gonzalez, Fleming, and Fowler, are much more difficult, especially if they involve serious criminal charges, such as murder and sexual battery on a very young minor. A court may be faced with the proverbial "hard case" and have to decide whether it should create an exception, thereby achieving a fair result in the case but making "bad law." Should fundamental fairness prevail or should the court follow a clearly-cut legal principle?

It is interesting to note that not one of the criminal cases discussed in this paper involved criminal wiretapping charges. In other words, in no case did the prosecution attempt to convict someone for illegally and surreptitiously taping an interstate telephone conversation. One might imagine a court in an all-party consent state convicting someone for surreptitiously taping an interstate telephone conversation if the taping occurred in an all-party consent state. It would be possible for an all-party consent state to prosecute someone for surreptitiously taping an interstate telephone conversation if the person whose conversation was taped was located in an all-party consent state, and if the taping occurred in a one-party consent state; however, as indicated by the Kearney court, the prosecution would very likely be loathe to bring such a charge because of problems with jurisdiction and the constitutionality of securing a conviction.

215. See Restatement (Second) of Conflict of Laws $§ 6(2)(f)(1971)$. 


\section{CONCLUSION}

If people are to look to the law for guidance, they need to be able to predict how a court will decide a case. Thus, they are seeking a certain amount of stability in the law. A legal principle can be so stable that it appears almost rigid. A stable legal principle provides guidance but does not allow a certain amount of needed flexibility. A stable but rigid legal principle can produce unwarranted results. With a stable but rigid legal principle, a court struggles when deciding a moderately challenging case, not to mention a very challenging case.

Thus, besides being fairly stable, the law must be able to deal effectively with at least a moderately difficult case. One way to provide a court with the needed flexibility is to instruct the court to examine a number of factors in reaching a decision. Allowing the court to examine a number of factors provides the court with enough leeway to reach the right result, perhaps even in the very challenging case. The problem with giving a court this amount of added flexibility is that it may appear that the court has been given free reign, leaving people without guidance as to how a court will decide a future case.

As this paper shows, little about interstate taping seems predictable except that it would not be wise to tempt fate by surreptitiously taping a telephone conversation with a California resident. Two other truisms are: (1) if you want to escape liability, never tape a telephone conversation without all-party consent, and (2) never talk about anything incriminating during a telephone conversation.

A number of states have no decisions that one can rely on in predicting whether one could be liable for surreptitiously taping a conversation or whether an incriminating conversation would be suppressed. Even in those states with decisions, many of the decisions are from trial-level or intermediate appellate courts, with no decisions from the state court of last resort. Florida is an example of a state with no clear precedent because there are two different lines of cases decided by Florida intermediate appellate courts. One will not have a clear idea what the law is in Florida until a surreptitious taping case is decided by the Florida Supreme Court.

In examining the surreptitious interstate taping cases, there is no evidence of a trend except that a small minority of states vigorously defends the right to require all-party consent prior to someone taping a telephone conversation. Thus, the tension often present in the law between stability and flexibility seems nowhere more apparent than in the conflict of law area, perhaps because conflict of law necessarily requires a court, in making its decision, to examine the law of at least two jurisdictions. 